\title{
EFFECT OF SOME ESSENTIAL OILS FOR LIMITING EARLY BLIGHT (ALTERNARIA SOLANI) DEVELOPMENT IN POTATO FIELD
}

\author{
Nehal S. El-Mougy* \\ Department of Plant Pathology, National Research Centre \\ El-Behoos St., 12622, Giza Egypt
}

Received: December 28, 2008

Accepted: January 6, 2009

\begin{abstract}
The fungicidal effect of some essential oils against Alternaria solani one of the species that cause early blight of potato was evaluated under in vitro and field conditions. Effect of carnation, caraway, thyme oils and the chemical fungicide Ridomil MZ 72 at various concentrations on mycelial growth of $A$. solani was tested. Carnation oil had the strongest and most extensive inhibitory effect on fungal growth. Slightly less effective were caraway and thyme oils followed by the chemical fungicide. Extended field trails for two cultivation seasons proved that the application of essential oils twice as foliar spray had a superior effect to the fungicide treatment for reducing the early blight incidence comparing with untreated control. An opposite relationship between the disease incidence and concentrations of applied essential oils was observed. The increase in potato yield also followed the same trend. The highest reduction in disease incidence and yield increase was recorded in treatments with $1 \%$ of carnation, caraway and thyme oils in descending order. Ridomil MZ 72 applied at the dose recommended by manufactories had a low effect in this regard. Essential oils treatments might be used as easily applied, safe and cost effective control methods against such plant diseases.
\end{abstract}

Key words: Early blight; essential oils; control; potato

\section{INTRODUCTION}

Potatoes are one of the most important vegetable crops in the world. In Egypt potatoes are the largest horticultural export. In recent years the EU has accounted for about $70-90 \%$ of Egyptian potato export. Potato plants are attacked by several plant pathogens causing serious diseases during the growing season, this consisted approximately $19 \%$ of crop loss. In potatoes early blight disease occurs in most of production areas almost every year although it has a significant effect on yield only when frequent wetting of the foliage favours early and rapid symptom development. Estimating accurately total annual crop losses of any one particular disease is difficult. Values in the literature for measured crop losses due to early blight vary enormously from 5-78\% (Waals et al. 2004; Pasche et al. 2004, 2005). Alternaria solani and A. alternata (e.g. Germany and Poland) are the causal agents of early blight, and then are important foliar pathogens of potato worldwide. Susceptibility to infection is primarily determined by the age of the host plant; $A$. solani causes collar rot in tomato seedlings and early blight in mature tomato and potato (Rotem 1998). The primary infection occurs on older foliage early in the season and then the inoculum spreads to immature surfaces, such as young tubers. Early maturing varieties are more susceptible, and may show severe defoliation. The wide and indiscriminate use of chemical fungicides has been the cause of the appearance of resistant plant pathogens, leading to the occurrence of serious diseases. Due to this, there is an increasing interest to obtain alternative antimicrobial agents for using in plant disease control systems. One of the main procedures used in the research of biologically active substances is a systematic screening for the interaction between microorganisms and plant products. This procedure has been a source of useful agents to control the microbial survival (Salvat et al. 2001). Plant products of recognized antimicrobial spectrum could appear in food conservation systems as main antimicrobial compounds or as adjuvants to improve the action of other antimicrobial compounds (Kaur and Arora 1999). Among other chemical products, aromatic plants possess essential oils resulting from secondary metabolism. These substances have a great economic potential, especially in the food, pharmaceutical and perfumery sectors. Thus, the number of studies on the chemical composition and biological properties of these oils, as well as the taxonomic, environmental and cultivation factors that lead to variation in their quantity and quality, has been increasing (Simões et al. 2003).

The objective of this research was to evaluate the effects of some plant oils as natural products and bio-pesticides and in vitro inhibition of $A$. solani in laboratory assays and determine the effect of natural products on the development and suppression of early blight disease under field conditions. 


\section{MATERIALS AND METHODS}

\section{Pathogen}

A pathogenic isolate of $A$. solani was obtained from Plant Pathology Department, National Research Centre, Dokki, 12622, Giza, Egypt. This isolate was certified as highly aggressive and causing a severe early blight disease on potato plants.

\section{Plant}

Potato tubers (Solanum tuberosum L.) cv. Diamond obtained from Vegetables Crop Research Department, Agricultural Research Centre, Giza, Egypt were used in the present study.

\section{Essential oils}

Commercial essential oils of carnation (a.s. Eugenol $60 \%$ ), caraway (a.s. Carvone 50\%) and thyme (a.s. Thymol $60 \%)$, respectively, were used in the present work. Essential oils used in the study were obtained from Chemical Industrial Development Company (CID), Egypt.

\section{Fungicide}

The fungicide Ridomil MZ 72 WP, was used as a positive control to the essential oils. Ridomil MZ 72 WP produced by Syngenta, Bazil, Switzerland contains: metalaxyl 8\% (fenylamole) and mancozeb 64\% (dithiocarbamate complex) with zink salt.

\section{Laboratory Tests}

The inhibitory effect of the essential oils and fungicide was evaluated measuring the linear growth of $A$. solani in vitro. For each of the essential oil three concentrations were prepared and tested. They were added individually to conical flasks containing sterilized PDA medium before its solidification to obtain concentrations of 0.25 , 0.5 and $1.0 \%(\mathrm{v}: \mathrm{v})$. In addition, different volumes of stock solution of the fungicide Ridomil MZ 72 WP were added to other conical flasks containing PDA to obtain concentrations of 50, 100, 200 and 400 ppm. A separate PDA flask free of either essential oils or fungicide was used as check (control) treatment. The supplemented media were poured into Petridishes $(9 \mathrm{~cm} \varnothing)$ nearly $20 \mathrm{ml}$ per each. Mycelial discs ( $5 \mathrm{~mm} \varnothing$ ) taken from the periphery of an actively growing PDA culture of $A$. solani were placed at the centre of the prepared Petri dishes, then incubated for seven days at $25 \pm 2^{\circ} \mathrm{C}$. Five replicates were used for each treatment. The diameter of colonies was measured and reduction in fungal growth was calculated in relative to check treatment.

\section{Field experiment}

A field experiment was carried out at Al-Aiat county, Giza governorate during 2006 and 2007 summer (January-April) growing seasons to evaluate the efficacy of carnation, caraway and thyme essential oils application on disease incidence and severity of early blight of potato plants under natural field conditions. The fungicide Ridomil MZ 72 WP was used in this study as a comparison. Carnation, caraway and thyme essential oils were used as plant foliar spray (at 4-5 true leaf stage) at concentrations of $0.25,0.50$ and $1.0 \%$. Stock solutions $(1000 \mathrm{ml})$ of each tested essential oil were prepared at the above mentioned concentrations by dissolving in sterilized distilled water and used for foliar spray. One $\mathrm{ml}$ of the emulsifier Tween $80(0.1 \%$ of water volume $)$ was added to the essential oil solutions to obtain an aqueous emulsion. The fungicide Ridomil MZ 72 WP was applied as a foliar spray at the recommended dose $(2.5 \mathrm{~kg} / \mathrm{ha})$. All treatments were applied twice with 15 days interval. A field experiment consisted of plots $3 \times 7 \mathrm{~m}$ each comprising of 7 rows and 15 holes/row and was conducted in completely randomized block design with five plots as replicates for each particular treatment and untreated check. Potato tubers cv. Diamond were planted in all treatments. All plots received traditional agricultural practices such as irrigation and fertilization. The used mineral fertilization of NPK was 180; 75 and 95 unit/feddan $\left(4200 \mathrm{~m}^{2}\right)$. In addition to $20 \mathrm{~m}^{2}$ organic manure and $300 \mathrm{~kg} / \mathrm{ha}$ agricultural sulpher were added to the soil before planting. Early blight disease incidence and severity were recorded after 10 days of the second plant spraying. The average harvested yield was calculated for all applied treatments as $\mathrm{kg} / \mathrm{plot}$ at the end of each growing season.

\section{Disease assessment}

Early blight incidence was estimated as the number of infected plants showing disease symptoms in relation to the whole number of potato plants per each plot. The average of records of the surveyed replicates (plots) for each particular treatment was calculated. Disease severity and early blight incidence was estimated using the disease scale from 0 to 4 suggested by Cohen et al. (1991) as follows: $0=$ no leaf lesion; $1=$ lesions on $<25 \%$ of leaf area; 2 = lesion on $26-50 \%$ of leaf area; $3=$ lesion on $51-75 \%$ of leaf area and $4=$ lesions on 76 up to $100 \%$ of leaf area. Then the following formula was used:

$$
\text { D.S. }=\frac{\sum(\mathrm{n} \times \mathrm{c})}{\mathrm{N}}
$$

where:

D.S. $=$ Intensity of attack, $\mathrm{n}=$ Number of infected plants per category, $\mathrm{c}=$ Category number and $\mathrm{N}=$ Total examined plants.

\section{Statistical analysis}

One way analysis of variance (ANOVA) was used to analyze differences between toxic concentrations of essential oils, fungicide and the linear growth of $A$. solani as well as differences between toxicity of essential oils, fungicide and early blight incidence at different applied concentrations under laboratory and field conditions. MSTAT-C program (V2.1) was used to perform the analysis of variance of toxicity of essential oils, fungicide and early blight incidence at different applied concentrations under field conditions. Duncan's Multiple Range Test was used for means separation (Winer 1971). 


\section{RESULTS}

\section{Laboratory tests}

The inhibitory activity against mycelial growth of A. solani was observed at all concentrations of carnation, caraway, thyme oils and the chemical fungicide Ridomil MZ 72 WP (Table 1). The Mycelial growth decreased significantly with the increase in concentrations of either essential oils or fungicide and reached minimum mycelial growth at the highest concentration used. A complete inhibition of fungal growth was observed at $1 \%$ of carnation oil. At the same concentration caraway and thyme oils caused a high reduction in fungal mycelial growth of 85.4 and $79.3 \%$, respectively.

Obtained data also show that the mycelial growth of A. solani was completely inhibited at $400 \mathrm{ppm}$ of Ridomil MZ 72 WP. At the other concentrations Ridomil MZ 72 WP gave nearly similar results as the tested essential oils having no superior quality over them.

\section{Field experiment}

The efficacy of certain essential oils as foliar spray against early blight disease incidence and severity of potato was evaluated under field conditions. Data in table 2 clearly demonstrate that all treatments significantly reduced disease incidence the two cultivation seasons. A variable order was observed regarding the protective effect of essential oils against early blight incidence, ranging between (27.0-36.8\%) and (33.3 to $39.0 \%)$ in the two successive cultivation seasons. Less significant reduction of $20.1 \%$ and $23.4 \%$ was observed for Ridomil MZ 72 WP, although it could significantly reduce disease incidence over the control treatment. In the first season of 2006, carnation, caraway, thyme oils of at applied concentration of $1 \%$ reduced significantly the disease incidence by 36.8 , 32.8 and $31.0 \%$ respectively, comparing with $14.4 \%$ caused by Ridomil MZ 72 WP. Obtained data also show that at the first cultivation season 2006, application of essential oils lead to a significant reduction in severity of early blight

Table 1. In vitro linear growth of $A$. solani in response to different concentrations of essential oils and Ridomil-Mancozeb

\begin{tabular}{|c|c|c|c|}
\hline Treatments ${ }^{\mathrm{C}}$ & Concentration & Linear growth [mm] & Reduction $^{\mathrm{B}}[\%]$ \\
\hline \multirow{3}{*}{$\begin{array}{c}\text { Carnation } \\
\text { (\% v:v) }\end{array}$} & 0.25 & $46.7 \mathrm{c}$ & 48.1 \\
\hline & 0.50 & $15.3 \mathrm{e}$ & 83.0 \\
\hline & 1.00 & $0.0 \mathrm{f}$ & 100 \\
\hline \multirow{3}{*}{$\begin{array}{c}\text { Caraway } \\
\text { (\% v:v) }\end{array}$} & 0.25 & $58.7 \mathrm{c}$ & 34.7 \\
\hline & 0.50 & $32.2 \mathrm{~cd}$ & 64.2 \\
\hline & 1.00 & $13.1 \mathrm{e}$ & 85.4 \\
\hline \multirow{3}{*}{$\begin{array}{l}\text { Thyme } \\
\text { (\% v:v) }\end{array}$} & 0.25 & $64.2 \mathrm{~b}$ & 28.6 \\
\hline & 0.50 & $53.2 \mathrm{c}$ & 40.8 \\
\hline & 1.00 & $17.6 \mathrm{e}$ & 80.4 \\
\hline \multirow{4}{*}{ Ridomil MZ 72 WP [ppm] } & 50 & $66.6 \mathrm{~b}$ & 26.0 \\
\hline & 100 & $52.1 \mathrm{c}$ & 42.1 \\
\hline & 200 & $38.6 \mathrm{~cd}$ & 57.1 \\
\hline & 400 & $0.0 \mathrm{f}$ & 100 \\
\hline \multicolumn{2}{|c|}{ Control } & 90 a & - \\
\hline
\end{tabular}

${ }^{\mathrm{A}}$ mean values within columns followed by the same letter are not significantly different at $\mathrm{p}<0.05$

${ }^{\mathrm{B}}$ reduction in fungal growth at different treatment, calculated relatively to its growth in untreated control

${ }^{\mathrm{C}}$ concentrations of essential oils were calculated as (v:v) of the growth medium, based on the active ingredient of the fungicide as ppm

Table 2. The influence of some essential oils application on early blight incidence and severity of potato plants during two summer cultivation seaeons (2006 and 2007) ${ }^{\mathrm{A}}$

\begin{tabular}{|c|c|c|c|c|c|c|c|c|c|}
\hline \multirow[b]{2}{*}{ Treatment } & \multirow[b]{2}{*}{ Concentration } & \multicolumn{4}{|c|}{ Season 2006} & \multicolumn{4}{|c|}{ Season 2007} \\
\hline & & incidence $^{\text {B }}$ & $\begin{array}{c}\text { reduction } \\
{[\%]}\end{array}$ & severity $^{C}$ & $\begin{array}{c}\text { reduction } \\
{[\%]}\end{array}$ & incidence $^{\text {B }}$ & $\begin{array}{c}\text { reduction } \\
{[\%]}\end{array}$ & severity ${ }^{\mathrm{C}}$ & $\begin{array}{c}\text { reduction } \\
{[\%]}\end{array}$ \\
\hline \multirow{3}{*}{$\begin{array}{c}\text { Carnation } \\
{[\%]}\end{array}$} & 0.25 & $12.2 \mathrm{bc}$ & 29.9 & $55.7 \mathrm{~b}$ & 29.6 & $12.3 \mathrm{c}$ & 35.9 & $51.4 \mathrm{~b}$ & 31.1 \\
\hline & 0.50 & $11.8 \mathrm{~d}$ & 32.2 & $52.7 \mathrm{c}$ & 33.5 & $12.0 \mathrm{~d}$ & 37.5 & $48.7 \mathrm{c}$ & 34.7 \\
\hline & 1.00 & $11.0 \mathrm{~d}$ & 36.8 & $43.8 \mathrm{e}$ & 44.7 & $11.7 \mathrm{~d}$ & 39.0 & $40.6 \mathrm{~cd}$ & 45.6 \\
\hline \multirow{3}{*}{$\begin{array}{c}\text { Caraway } \\
{[\%]}\end{array}$} & 0.25 & $12.5 \mathrm{~b}$ & 28.2 & $57.3 \mathrm{c}$ & 27.7 & $12.8 \mathrm{bc}$ & 33.3 & $55.4 \mathrm{~b}$ & 25.7 \\
\hline & 0.50 & $12.0 \mathrm{bc}$ & 31.0 & $48.8 \mathrm{~cd}$ & 38.4 & $12.1 \mathrm{c}$ & 37.0 & $44.5 \mathrm{c}$ & 40.3 \\
\hline & 1.00 & $11.7 \mathrm{~d}$ & 32.8 & $41.2 \mathrm{e}$ & 48.0 & $11.8 \mathrm{~d}$ & 38.5 & $40.2 \mathrm{~cd}$ & 46.1 \\
\hline \multirow{3}{*}{$\begin{array}{c}\text { Thyme } \\
{[\%]}\end{array}$} & 0.25 & $12.7 \mathrm{~b}$ & 27.0 & $59.7 \mathrm{c}$ & 24.6 & $12.6 \mathrm{~b}$ & 34.4 & $54.8 \mathrm{~b}$ & 26.5 \\
\hline & 0.50 & $12.1 \mathrm{~b}$ & 30.5 & $47.6 \mathrm{~cd}$ & 39.9 & $12.0 \mathrm{~b}$ & 37.5 & $45.8 \mathrm{c}$ & 38.6 \\
\hline & 1.00 & $12.0 \mathrm{~b}$ & 31.0 & $41.6 \mathrm{e}$ & 47.5 & $11.9 \mathrm{~b}$ & 38.0 & $39.7 \mathrm{~cd}$ & 46.8 \\
\hline \multicolumn{2}{|c|}{$\begin{array}{c}\text { Ridomil MZ } 72 \text { WP } \\
{[2.5 \mathrm{~kg} / \mathrm{ha}]}\end{array}$} & $13.9 \mathrm{~d}$ & 20.1 & $63.4 \mathrm{f}$ & 19.9 & $14.7 \mathrm{~cd}$ & 23.4 & $61.4 \mathrm{e}$ & 17.7 \\
\hline \multicolumn{2}{|c|}{ Control } & $17.4 \mathrm{a}$ & - & $79.2 \mathrm{a}$ & - & $19.2 \mathrm{a}$ & - & $74.6 \mathrm{a}$ & - \\
\hline
\end{tabular}

${ }^{\text {A }}$ mean values within columns followed by the same letter are not significantly different at $\mathrm{p}<0.05$

${ }^{\mathrm{B}}$ early blight incidence was estimated as the number of infected plants showing disease symptoms in relation to the whole number of potato plants per each plot

${ }^{\mathrm{C}}$ disease severity of early blight incidence was estimated using the disease scale from 0 to 4 suggested by Cohen et al. (1991) 
Table 3. The influence of some essential oils application on potato yield during two summer cultivation seasons (2006 and 2007$)^{\mathrm{A}}$

\begin{tabular}{|c|c|c|c|c|c|}
\hline \multicolumn{2}{|c|}{ Season 2007} & \multicolumn{2}{|c|}{ Season 2006} & \multirow[b]{2}{*}{ Concentration } & \multirow[b]{2}{*}{ Treatment } \\
\hline $\begin{array}{c}\text { increase }^{\mathrm{C}} \\
{[\%]}\end{array}$ & $\begin{array}{c}\text { yield }^{\mathbf{B}} \\
{[\mathrm{kg} / \mathrm{plot}]}\end{array}$ & $\begin{array}{c}\text { increase }^{\mathrm{C}} \\
{[\%]}\end{array}$ & $\begin{array}{c}\text { yield }^{\mathbf{B}} \\
{\left[\mathrm{kg} / \mathrm{plot}^{2}\right.}\end{array}$ & & \\
\hline 32.9 & $61.4 \mathrm{bc}$ & 29.2 & $62.0 \mathrm{c}$ & 0.25 & \multirow{3}{*}{ carnation [\%] } \\
\hline 39.6 & $64.5 \mathrm{~d}$ & 33.6 & $64.2 \mathrm{c}$ & 0.50 & \\
\hline 49.1 & $68.9 \mathrm{~d}$ & 43.3 & $68.8 \mathrm{~cd}$ & 1.00 & \\
\hline 20.7 & $55.8 \mathrm{~b}$ & 26.9 & $60.9 \mathrm{c}$ & 0.25 & \multirow{3}{*}{ caraway [\%] } \\
\hline 26.6 & $58.5 \mathrm{~b}$ & 31.3 & $63.0 \mathrm{c}$ & 0.50 & \\
\hline 47.2 & $68.0 \mathrm{~d}$ & 38.8 & $66.6 \mathrm{~cd}$ & 1.00 & \\
\hline 26.8 & $58.6 \mathrm{~b}$ & 17.7 & $56.5 \mathrm{~b}$ & 0.25 & \multirow{3}{*}{$\begin{array}{c}\text { thyme } \\
{[\%]}\end{array}$} \\
\hline 33.1 & $61.5 \mathrm{bc}$ & 20.8 & $58.0 \mathrm{~b}$ & 0.50 & \\
\hline 40.0 & $64.7 \mathrm{~d}$ & 22.1 & $58.6 \mathrm{~b}$ & 1.00 & \\
\hline 23.8 & $57.2 \mathrm{~b}$ & 4.4 & $50.1 \mathrm{ab}$ & \multicolumn{2}{|c|}{$\begin{array}{c}\text { Ridomil MZ } 72 \text { WP } \\
{[2.5 \mathrm{~kg} / \mathrm{ha}]}\end{array}$} \\
\hline- & $46.2 \mathrm{a}$ & - & $48.0 \mathrm{a}$ & \multicolumn{2}{|c|}{ control (untreated) } \\
\hline
\end{tabular}

${ }^{\text {A }}$ mean values within columns followed by the same letter are not significantly different at $\mathrm{p}<0.05$

${ }^{B}$ yield rated as average $\mathrm{kg} / \mathrm{plot}\left(21 \mathrm{~m}^{2}\right)$ of potato tubers weight at different treatments

${ }^{C}$ yield increase at different treatments calculated relatively to untreated control

disease estimated as 24.6 up to $48.0 \%$ comparing with $19.9 \%$ for the fungicide treatment. A similar trend was also observed in the second cultivation season 2007.

The potato tuber harvested yield, in all treatments, was significantly higher than control and amounted to $4.4-43.3 \%$ and $23.8-49.1 \%$ in the two cultivation seasons in respective order (Table 3 ). Highly effective treatments induced the obvious increases of tuber yield being for $1 \%$ carnation oil (43.3 and $49.1 \%$ ) followed by caraway oil (38.8 and 47.2\%) and thyme oil (22.1 and 40.0\%) in 2006 and 2007 cultivation seasons, respectively. The lowest increase in potato yield (4.4 and $23.8 \%$ ) was observed for fungicide treatment.

\section{DISCUSSION}

The potential use of natural products for early blight management can promote reduced inputs and improve sustainability of potato production. Therefore, the objective of the present research was to evaluate the effects of essential oils in vitro inhibition of $A$. solani in laboratory assays and determine their effectiveness in the development and suppression of early blight disease under natural field conditions. A complete inhibition of linear fungal growth was achieved with carnation oil at concentration of $1 \%$ and fungicide at a highest dose. Over $80 \%$ reduction of in vitro growth was also recorded for caraway and thyme oil amendments at the same concentration and this differed significantly from fungicide treatment. Under field conditions, the protective foliar application of carnation, caraway and thyme oils resulted in a variable disease suppression of 36.8 and $39.0 \%$ as related to the untreated control. Similar trend was also observed for the increase of potato tuber yield throughout the two successive seasons.

It is well established that some plants contain compounds able to inhibit the microbial growth (Naqui et al. 1994). These plant compounds can be of different structures and different mode of action when compared with antimicrobials conventionally used to control the microbial growth and survival (Nascimento et al. 2000). Potential antimicrobial properties of plants had been related to their ability to synthesize, by the secondary metabolism, several chemical compounds of relatively complex structures with antimicrobial activity, including alkaloids, flavonoids, isoflavonoids, tannins, cumarins, glycosides, terpens, phenylpropannes, organic acids (Nychas 1996). The aesthetic, medicinal and antimicrobial properties of plant essential oils have been known since ancient times. Numerous studies on the fungicidal and fungistatic activities of essential oils have indicated that many of them have the power to inhibit fungal growth. The ISO (International Standard Organization) defines essential oils as the products obtained from parts of plants through steam distillation, as well as by pressing the pericarps of citric fruits. In general, they are composed of complex mixtures of volatile, lipophilic, liquid and odiferous substances. They may also be described as volatile oils, ethereal oils and essences (Simões et al. 2003).

Thyme oil proved to be extremely effective as a fumigant as well as a contact fungicide against a range of the economically significant fungi Alternaria spp., Aspergillus spp., Botrytis cinerea, Erysiphe graminis (Alefyah and Avice 1997). Moreover, caraway products are used as sprouting inhibitors, and they also considerably reduce losses caused by storage fungi (Bång 1995a, 1995b, 1999). Caraway essential oil delayed the onset of late blight for about 10-14 days under field conditions (Hannukkala et al. 2002; Keskitalo 2002). The control activity of the oil is based on prevention of late blight sporangia production and growth already at a low oil concentration. El-Toony et al. (2003) studied the biochemical reaction of onion, garlic, eucalyptus, caraway, fennel, black cumin, mustard, carnation, neemix and trilogy essential oils against mycelial growth of $R$. solani and Pythium de-baryanum in vitro. They found that complete inhibition of both fungi was obtained by only carnation oil at $4 \%$, while considerable inhibition (more than $90 \%$ ) was obtained by neemix and 
trilogy oils. Furthermore, the essential oil from Melaleuca alternifolia has also shown potential to reduce disease incidence and severity from foliar A. solani on potato and Cercospora beticola on sugar beets (Caolotanski et al. 2002). The information was found in the literature concerning mode of action of essential oils on/in the fungal cell in order to promote fungistatic or fungicide effect. In general, inhibitory action of natural products on moulds involves cytoplasm granulation, cytoplasmic membrane rupture and inactivation and/or inhibition of intercellular and extracellular enzymes. These biological events could take place separately or concomitantly culminating with mycelium germination inhibition (Campo et al. 2003). Also, it is reported that plant lytic enzymes act in the fungal cell wall causing breakage of b-1,3 glycan, b-1,6 glycan and chitin polymers (Brull and Coote 1999). The mode by which microorganisms are inhibited by essential oils and their chemical compounds seem to involve different mechanisms. It has been hypothesized that the inhibition involves phenolic compounds, because these compounds sensitize the phospholipid bilayer of the microbial cytoplasmic membrane causing increased permeability and unavailability of vital intracellular constituents (Juven et al. 1994). Reports indicated that essential oils containing carvacrol, eugenol and thymol (phenolic compounds) had the highest antibacterial performances (Kim et al. 1995).

The present results may lead to the conclusion that application of essential oils is applicable, safe and cost-effective method for controlling such foliar diseases. Also, the use of essential oils in agriculture could be a suitable alternative for inclusion in disease control systems and could act sometimes as main or adjuvant antimicrobial compounds and do not leave a toxic residue in the product.

\section{REFERENCES}

Alefyah A., Avice M.H. 1997. The fungicidal properties of plant extracts and essential oils. Plant Pathology-Global Perspectives of an Applied Science. E: \potato \The BSPP-ArchivesBSPP Presidential Meeting 1997.htm (Offered Poster).

Bång U. 1995a. Natural plant extracts-control of fungal pathogens of potato. Proc. of the Swedish crop protection conference: Svenska Växtskyddskonferencen: Jordbruk Skadedjur, växtsjukdomar och ogres: 371-381.

Bång U. 1995b. Essential oils as fungicides and sprout inhibitors in potatoes. p. 318- 324. In: Proc. of the EAPR pathology section meeting "Phytophthora infestans 150" (L.J. Dowley, E. Bannon, L. Cooke, T. Keane, E. OSullivan, eds.). Dublin, 10-16 September, 1995.

Bång U. 1999. Control of seed borne pathogens by natural volatile substances. In: Abstracts of the EAPR 14th triennial conference .Sorrento, 2-7 May 1999.

Brull S., Coote P. 1999. Preservative agents in foods: mode of action and microbial resistance mechanisms. Inter. J. Food Microbiol. 50: 1-17.

Caolotanski J.M., Hanson L.E., Hill A.L., Hill J.P. 2002. Use of Melaleuca alternifolia oil for plant disease control. Phytopathology 92, p. 512.

Campo J., Nguyen-The C., Sergent M., Amito M.J. 2003. Determination of most bioactive phenolic compounds from rose- mary against Listeria monocytogenes: influence of concentration, $\mathrm{pH}$ and NaCl. J. Food Sci. 68: 2066-2071.

Cohen Y., Gisi U., Mosinger E. 1991. Systemic resistance of potato plants against Phytophthora infestans induced by unsaturated fatty acids. Physiol. Mol. Pl. Pathol. 38: 255-263.

El-Toony A.M.E., Awad N.G.H., Tadrous M.F.I. 2003. Chemical and biochemical control of tomato damping-off disease under nursery conditions with special reference to the antagonism between the causal pathogens. Egypt. J. Appl. Sci. 18: 47-68.

Hannukkala A., Keskitalo M., Laamanen J., Rastas M. 2002. Control of potato late blight with Caraway and Dill extracts. p. 279-280. In:. Proc. of the sixth workshop of a European network for development of an integrated control strategy of potato late blight (H.T.A.M. Schepers, C.E. Westerdijk, eds.). 26-30 September 2001, Edinburgh, Scotland.

Juven B.J., Kanner J., Sched F., Weisslowicz H. 1994. Factors that interact with the antibacterial of thyme essential oil and its active constituents. J. Appl. Microbiol. 76: 626-631.

Kaur J., Arora D. 1999. Antimicrobial activities of species. Int. J. Antimicrob. Agents. 12: 257-262.

Keskitalo M. 2002. Production and composition of antimicrobial extracts from caraway. In: Abstract book, 5th European Symposium Industrial Crops and Products. Amsterdam, 24-26 April 2002, 95 pp.

Kim J., Marshall M.R., Wei C. 1995. Antibacterial activity pf some essential oils components against five foodborne pathogens. J. Agric. Food Chem. 43: 2839-2845.

Naqui S.H.A., Khan M.S.Y., Vohora S.B. 1994. Antibacterial, antifungal and anthelmintic investigation on Indian medicinal plants. Fitoterapia 62: 221-228.

Nascimento G.G., Locatelli J., Freitas P.C. 2000. Antibacterial activity of plants extracts and phytochemical on antibiotic resistant bacteria. Braz. J. Microbiol. 31: 247-256.

Nychas G.J.E. 1996. Natural antimicrobial from plants. p. 235258. In: "New Methods of Food Preservation" (G.W Gould, ed.). Londres, CRC Press.

Pasche J.S., Wharam C.M., Gudmestad N.C. 2004. Shift in sensitivity of Alternaria solani in response to Q (0) I fungicides. Plant Dis. 88: 181-187.

Pasche J.S., Piche L.M., Gudmestad N.C. 2005. Effect of the F129L mutation in Alternaria solani on fungicides affecting mitochondrial respiration. Plant Dis. 89: 269-278.

Rotem J. 1998. The Genus Alternaria; Biology, Epidemiology, and Pathogenicity. APS Press, St. Paul, Minnesota.

Salvat A., Antonnacci L., Fortunato R.H., Suarez E.Y., Godoy H.M. 2001. Screening of some plants from Northern Argentine for their antimicrobial activity. Lett. Appl. Microbiol. 33: 93-297.

Simões C.M.O., Schenkel E.P., Gosmann G., Mello J.C.P., Mentz L.A., Petrovick P.R. 2003. Farmacognosia da Planta ao Medicamento. 5th ed. UFRGS/UFSC: Porto Alegre/Florianópolis.

Waals J.E., Korsten L., Slippers B. 2004. Genetic diversity among Alternaria solani isolates from potatoes in South Africa. Plant Dis. 88: 959-964.

Winer B.J. 1971. Statistical Principles in Experimental Design. 2nd ed. MiGraw-Hill Kogakusha, LTD. 


\section{POLISH SUMMARY}

\section{DZIAŁANIE OLEJKÓW ETERYCZNYCH}

\section{NA ROZWÓJ WCZESNEJ ALTERNARIOZY (ALTERNARIA SOLANI) W UPRAWIE ZIEMNIAKA}

$\mathrm{W}$ warunkach polowych oraz in vitro badano grzybobójcze działanie niektórych olejków eterycznych przeciwko Alternaria solani, który jest grzybem wywołującym wcześnie występującą alternariozę. Przedmiotem badań były różne stężenia olejków z goździka, kminku oraz tymianku i chemiczny fungicyd Ridomil MZ 72. Olejek z goździka najlepiej inhibitował wzrost grzyba $A$. solani. Nieco mniej efektywne były olejki z kminku i tymianku, natomiast fungicyd chemiczny działał najsłabiej. Szeroko zakrojone badania polowe prowadzone $\mathrm{w}$ dwóch sezo- nach wegetacyjnych wykazały, że dwukrotne zastosowanie opryskiwania liści ziemniaka olejkami eterycznymi lepiej ograniczało występowanie choroby niż Ridomil MZ 72, w porównaniu do nietraktowanej kombinacji kontrolnej. Stwierdzono pozytywną zależność między efektywnością działania wzrastających stężeń olejków a ograniczeniem choroby, oraz pozytywny wpływ tych zabiegów na wysokość plonu. Najlepsze ograniczenie występowania choroby i najwyższy wzrost plonu uzyskano stosując olejek z goździka, a następnie olejki z kminku i tymianku. Działanie Ridomilu MZ 72 użytego w dawce zalecanej przez producenta było słabe. Wykorzystanie olejków eterycznych do zwalczania tego rodzaju chorób może stanowić łatwa, bezpieczną i opłacalną ekonomicznie metodę ochrony roślin. 